УДК 94(477+438)“'1921-1939”

ЛИТВИН М.Р.

https:// orcid.org /000-0002-4969-052X

https://doi.org/10.33577/2313-5603.32.2019.241-244

\title{
НА ЗАХИСТІ ПОЛЬСЬКОЇ ДЕРЖАВИ
}

Ostanek Adam Adrian. W służbie Ojczyżnie. Wojsko Polske w systemie bezpieczeństwa wojewódstw południowo-wschodnich II Rzeczypospolitej (19211939). Warszawa, 2019. $516 \mathrm{~s}$.

Військо завжди є стержнем, фундаментом будь-якої держави. Тож не дивно, що відомий варшавський військовий історик Адам Останек звернувся до цієї актуальної теми. Нині, як і тоді - у міжвоєнну добу XX ст., знову існує загроза розв'язання нових локальних чи гібридних війн. У зв'язку із цим науково актуальною є рецензована книга, яка реконструює розбудову структур польського війська у Східній Галичині після Першої світової війни, поразки Західно-Української Народної Республіки

Нова книга має добре джерельне підгрунтя, автор знає сучасну польську та зарубіжну історіографію, вміє логічно викладати матеріал і робити виважені висновки. Науковою, а водночас цікавою $є$ мова викладу матеріалу.

Перший розділ праці актуалізує роль і місце Східної Галичини, яка була інкорпорована до Другої Речі Посполитої в ході Версальсько-Вашингтонських домовленостей після Першої світової війни й стала складовою системи безпеки країни у міжвоєнну добу. За матеріалами офіційних переписів населення автор реконструював етнодемографічний розвиток воєводств цього краю, конфесійний і соціальний стан поліетнічного населення. Показав значення цього прикордонного терену для фінансово-господарського розвитку держави (Прикарпаття, як відомо, славилося своїми мінеральними ресурсами, тваринництвом, сільськогосподарською переробкою), зміцнення східного кордону Польщі з тоталітарним

Литвин Микола Романович, доктор історичних наук, професор, провідний науковий співробітник науково-дослідної лабораторії (військово-історичних досліджень) Наукового центру Сухопутних військ, м. Львів.

(C) Литвин М.P., 2019 
СРСР, який у 30-ті роки активного готувався до поширення світової комуністичної революції, нових воєнних інкорпорацій. Це, зрештою, засвідчив пакт Молотова-Ріббентропа 1939 року.

Найбільше уваги А. Останек приділяе розбудові Округу VI «Львів», життєдіяльності окремих військових формувань у містах Стрий, Долина, Яворів, Кам'янка Струмилова, Станиславів, Коломия, Дрогобич, Тернопіль, Ходорів, Броди, Городок, Калуш, Жидачів, Надвірна, Заліщики, Золочів, Бережани, Жовква, Теребовля, Чортків та ін., їхньому реформуванню в 1924, 1927, 1929, 1930, 1933, 1939 роках. Підкреслено, що у цьому краї у другій половині 30-х років. започатковано формування сучасних бронемоторних частин польського війська.

Наступні розділи книги розкривають проблему у хронологічному розвитку. Зокрема у другому розділі показано ставлення національних меншин держави, серед них і українців, до перших призовів до війська, загалом до служби у регулярній армії. Новаторським $є$ сюжет про допризовний вишкіл молоді, участь у цьому процесі довоєнних і нових парамілітарних структур.

У третьому розділі зібрано оригінальний документальний матеріал, який показує роль та місце армії у національній політиці Другої Речі Посполитої, яка мала за мету толерувати суспільнокультурний простір національних меншин (влада дозволяла діяльність національних товариств, окремих партій, кооперації та ін.), нейтралізувати їхні політичні сепаратистські настрої і радикальні дії до центральної та місцевої влади. Добре виписано ставлення громадськості до збройних сил Польщі й особи військового.

Схвально і те, що автор зібрав великий емпіричний матеріал про щоденне життя і побут військовиків, численні культурні та спортивні події солдатів і офіцерів Львівського, Станіславського та інших гарнізонів, будівництво армійськими структурами нових спортивно-рекреаційних об'єктів, насамперед у Львові, які використовувало не тільки польське військо, але й цивільне населення Львова та регіону.

Охарактеризовано у книзі особливості суспільно-політичного життя в регіоні міжвоєнної доби, за якими пильно слідкували силові структури держави. Автор вважає, що певний вплив на нього відігравала політика асиміляції щодо національних меншин, яку відстоювали польські націонал-демократи. Ворожим було ставлення українського селянства і до польських військових осадників, які 
виконували у регіоні не лише господарські, але й безпекові функціï. Осадницьку акцію започаткував урядовий наказ від 17 грудня 1920 р. «Про надання землі воякам Війська польського», згідно 3 яким у 1921-1923 pp. створено 7200 господарств осадників (c. 100-101). У книзі згадано і про бойкот українською молоддю на початку 20-х років призовних кампаній до війська, а також антипольські акції (зокрема терористичні щодо окремих поляків та українців, підпали фільварків, ін.) українських праворадикальних структур - УВО і ОУН, членами яких стали недавні вояки армій УНР і ЗУНР.

Згодом Провід ОУН не перешкоджав мобілізації українців до польської армії, вважаючи, що набутий військовий вишкіл знадобиться у майбутній збройній боротьбі проти окупантів. Автор наводить офіційну статистику, згідно з якою 1934 р. українці становили $17 \%$ всіх військовослужбовців регіону; більше $34 \%$ їх служило в кавалерії, а найменше $(0,65 \%)$ - у бронетанкових частинах. Євреї, як правило, служили у медико-санітарних підрозділах (с. 207).

Стверджено, що польське військове командування намагалося будь-якими засобами нейтралізувати пропаганду серед військових як правих (ОУН), так і лівих (КПЗУ) політичних сил (с. 115-219). Доводилося війську та Корпусу охорони пограниччя також ліквідовувати прокомуністичні «диверсійні групи», які засилалися в регіон із СРСР (с. 128-129). Долучалося військо і до забезпечення громадського спокою під час проведення українцями щорічних зеленосвяточних та листопадових акцій у Львові (Янівський цвинтар), Товсте, Перемишль та інших місцевостях. Автор наводить і назви частин із Львова, Городка, Рудок, Яворова, Перемишля, Збаража, Бережан, Підгайців, Бучача, Зборова, Теребовлі, Рогатина, які брали участь 1930 р. у репресійних акціях проти українських саботажників (с. 218-225).

Не обійдено увагою діяльність українських партій та політичних угруповань, зокрема центристського Українського національнодемократичного об'єднання, яке співпрацювало з владою.

Інформаційно насиченим $є$ параграф про польський парамілітарний рух між двома світовими війнами, участь сокільських та інших структур в організації вишкільних таборів молоді в Карпатах (Сколе, Мізунь, Делятин, Верхнє Синьовидне, Ворохта та ін.), спортивно-патріотичних змагань, курсів із стрілецтва, теренознавства та ін. Подано також маловідому інформацію про зв'язки 
частин із різними непольськими громадськими структурами (ств. 1933 р.) і Союзом загродової шляхти (ств. 1935 р.), діяльність яких оминають українські автори.

Охарактеризовано також військові приготування у регіоні напередодні Другої світової війни: передислокації військових частин, їх озброєння; надання зброї великим промисловим підприємствам (наприклад нафтовому концерну «Галичина» у Дрогобичі; нейтралізацію дій боївок ОУН як у Галичині, так і в Закарпатті; діалог із провідниками УНДО, які виступили за збройний захист Польської держави, творення в іiі складі повноцінної політичної, культурної, господарської автономії «українців» (с. 366-386). У цей час (18 лютого 1939 р.) за участю військовиків відкрито Гуцульський музей у Жаб'ю, вулицями Львова влаштовано патріотичний марш-похід «Гуцульський шлях II бригади легіонів».

У книзі об'єктивно розкрито ставлення до держави та ії війська керівників Греко-Католицької Церкви, інших церков. Показано ставлення місцевих євреїв і німців до Польської держави, іiі поліетнічного війська.

Щоправда, у майбутньому авторові необхідно більше уваги приділити службі недавніх старшин Армії Української Народної Республіки у Війську Польському (зрештою, про це вже писали О. Колянчук, О. Вішка, А. Руккас, В. Резмер та ін.), організації та облаштуванню польських та українських військових цвинтарів на території означених воєводств. Що ж до зауважень, то вважаємо, що автор не повинен послуговуватися етнонімом «русин», виокремлюючи його від українців. Небажаними є вживання слова «Малопольща» як географічного терміна.

Заслуговує схвалення іменний та географічний покажчики книги, укладена бібліографія. Важливо й те, що окремі висновки та сюжети праці апробовані на численних наукових конференціях, публікаціях у Польщі та Україні.

Загалом рецензована книга Адама Адріана Останека «W służbie Ojczyżnie. Wojsko Polske w systemie bezpieczeństw wojewódstw południowo-wschodnich II Rzeczypospolitey (1921-1939)» написана на належному науковому рівні й стане в нагоді не лише для фахових військових, істориків війська, але й для широкого кола читачів, які цікавляться новітньою історією Польщі та України, загалом країн Центрально-Східної Свропи. 